\title{
Rearing Practices of Rural Girls- A Situational Analysis Across Cultural Zones of Punjab
}

\author{
S. Thind, R. Mahal and Seema \\ Department of Human Development, Punjab Agricultural University, Ludhiana 141 004, \\ Punjab, India \\ E-mail: ritumahal@yahoo.co.in
}

KEYWORDS Status of Girl Child. Education. Domestic Work. Socialisation. Mate Selection

\begin{abstract}
The Punjab State is divided into three cultural zones i.e. Majha, Malwa and Doaba. A multi stage random sampling method was employed for the selection of the sample. The total sample of the study was 3600 adolescent girls. The girls were interviewed on the existing levels of schooling status, household responsibilities, upbringing practices, economic, social, health and marriage aspects. The girls in all the three cultural zones were of the view that discrimination between genders was felt in different rearing practices No matter, what amount of school work is there, the girls from all cultural zones have to give priority to their household responsibilities Girls were not allowed to go for movies /shopping, as this would bring bad name to their families. No social /religious functions are performed on birth of a baby girl.
\end{abstract}

\section{INTRODUCTION}

India is a country, which takes great pride in its cultural heritage, traditions and we grow up with the notion that ours is a country where women are worshipped. Often, examples are quoted from various scriptures, claiming to have given equal rights in social, cultural, political and educational spheres to all people regardless of sex, caste or creed. This cultural heritage picture stands in contrast to the one at present, which reflects great variance between preaching and practice. The purity of preaching is polluted with the abuse, torture and second class treatment being given to women who are invariably being glorified as mothers, daughters and wives. This drama of verbal glorification and factual abuse begins with a single incidence i.e. the birth of a girl in Indian society.

The history of women serves to highlight the ironies and contradictions of our society. Although women compromise a majority of the population, they nonetheless are often treated like a minority group, denied access to career and power in the public arena and viewed as dependant, weak and submissive by nature. The position of women continued to be degraded till 1800 A.D when lack of education, child marriages and the practice of sati brought about tremendous deterioration in her position at home and in society in general. Empirical studies regarding the status of women in India are recent in origin. Ramalingaswami (1996) examined the link between malnutrition, poor health, lack of education, overwork, lack of skills, mistreatment, powerlessness and the persistence of hunger in India and reported that the poor care that is afforded to girls and women by their husbands and by elders is the first major reason for levels of child malnutrition that are markedly higher in South Asia than anywhere else in the world.

However, since many of the contemporary studies concerning the attitudes towards the status of women is rooted in the past. Girls are considered a liability because of the emphasis laid upon the protection of the girls' honor. They are imagined to be an unproductive human resource as their contribution to the family and community is "invisible" although it is substantial (Shah 1998). Scholars working on the status of Indian women opine that many changes have occurred in the traditional conception of role and status of women through new opportunities for education and employment, emergence of new socio-economic pattern, and privileges of equal legal and political rights. Women are competing with men on an equal footing and have entered into occupations, which were considered as the domain of men (Desai 1957). However, the pressure of traditional customs and norms continue to determine the society's attitude towards women. The institute of caste and the patriarchal family system with religious mores and dominant value systems are still surcharges with the spirit 
of male domination. Women in rural areas lagged behind their counterparts in urban areas because different opportunities were not made available to them. If a women is married at a younger age and there is wide age gap between the husband and the wife she would have a lower status.

Male children receive more effective independence and encouragement than females because of cultural roles assigned to both sexes in adult life (Verma and Ghadially 1985). The implications are both for biological and social development. Therefore, gender is the crucial determinant of the course of life of individual.

Consciously and unconsciously our society, teachers, parents and media have been reinforcing the stereotypes of gender roles and expectations, with the result that girls find it almost impossible to break out of the mould that has been cast for them by society. The childhood and adolescence of our daughters are married by neglect, discrimination, lack of opportunities and limited employment options.

Thus, the present study is undertaken to study the rearing practices of rural girls across cultural zones of Punjab under the following objectives:

- To study the existing levels of schooling status, household responsibilities and upbringing practices of rural adolescent girls aged 13-18 years

- To study the existing levels of economic, social, health and marriage aspects of rural adolescent girls aged $13-18$ years

\section{METHODOLOGY}

The Punjab State is divided into three cultural zones i.e. Majha, Malwa and Doaba. A multi stage random sampling method was employed for the selection of the sample. Seventy two villages in thirty six blocks from all the three cultural zones: Malwa, Majha and Doaba falling in twelve districts of Punjab were selected for the study. School girls studying in classes $9^{\text {th }}$ and $10^{\text {th }}, 10+1$ and $10+2$ studying in government schools were drawn from seventy two villages of each cultural zone of Punjab. Thus, the total sample of the study was 3600 rural adolescent girls. Since, the area in Malwa zone is big in terms of area as more number of villages were selected in this zone. Figure1 depicts the distribution of villages and sample selection for the study

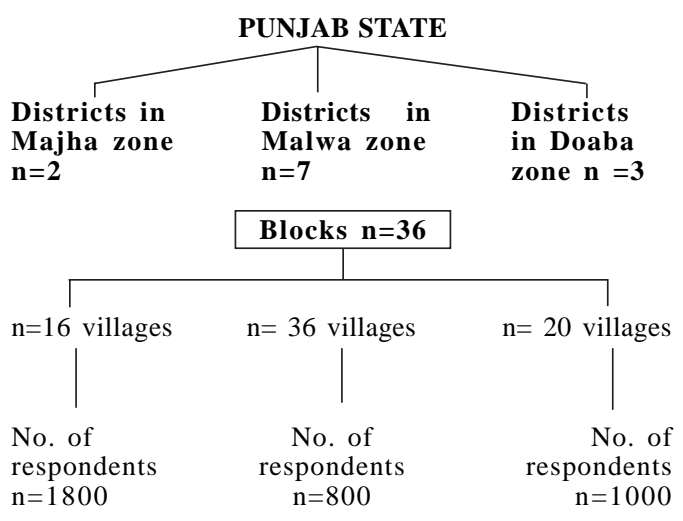

Fig. 1. Hence, total number of respondents $=\mathbf{3 6 0 0}$ No. of villages in cultural zones $n=72$

\section{Measurement Tools}

1. Interview Schedule: This along with group discussions was prepared for girls to assess their existing level of knowledge for the variables -Schooling Status; Household responsibilities; Upbringing practices; Economic Aspects; Social Aspects; Health Aspects; Marriage Aspects

2. Ethnographic Technique: Ethnographic technique allows a multifaceted interaction between the researcher and the participants thereby making the data collection process rich and dynamic. Through this approach one understands the culture of the social groups through participant observation by making extensive field notes and trying to capture the cultures unique values and social processes

\section{RESULTS AND DISCUSSION}

The girls studying in $9^{\text {th }}$ and $10^{\text {th }}, 10+1$ and $10+2$ classes were interviewed and observed on various aspects such as schooling status, household responsibilities, upbringing practices, economic, social, health, marriage and legal aspects etc. The results compiled, thus have been described under the following headings:

\section{Schooling Status}

The schooling status of girls in Malwa zone revealed that girls were very much interested in studies, to the extent that they were attending schools in the adjoining villages as either there was no school in their village or it was up to 
primary level. It was observed that only those girls go on foot where there is school availaible in the village whereas girls from nearby villages go to school by bus or cycle. Similarly, the girls in Doaba zone were very much interested to study no matter how far they had to travel. Majority (90\%) of the girls from all villages went to school on cycles in adjoining villages, covering a distance of $6-8 \mathrm{kms}$, as there was no high school in the village they reside. Whereas a few of them went on foot covering a distance of 2-4 kms approximately from their house to school. But, in Majha area, again most of the girls (90\%) come to school on foot and cycles. A few of them $(10 \%)$ come on buses or auto rickshaws. Girls who come on cycles, buses and autos, cover the distance of $4 \mathrm{kms}$ approximately from their houses to school. Most of the girls (75\%) spend one hour at home for studies, $13 \%$ spend two hours and rest of the girls $12 \%$ spend three hours for study. On average the girls spent spend 1-2 hours for studies at home with additional responsibilities of daily household chores. All the girls reported that both their parents encouraged them to study. Seventy five percent of the girls' fathers bring books/stationary items for them and for the rest $(20 \%)$ their mothers and $5 \%$ of brothers bring books/stationary items for girls. Hence, no girl herself went to market to get stationary/books. The overall picture depicts that the girls had to really work hard to go to school along with household chores, as these were considered more important than their education. It was also reported that their parents were very casual in meeting school teachers to know about the performance of their daughters and they visit the school only on being reminded by the school authorities for 2-3 times.

On contrary parents prefered to send their sons to English medium private schools with the understanding that such schools shape the personality of the child. They are ready to pay more tuition fee in private schools in comparison to government schools where their daughters were studying they believe that spending for education in case of sons is the investment for the family. Spending for education on daughters is considered wastage of money, as one-day daughters will have to leave the parental family after marriage. As reported by Rana (1995) that low literacy rate among rural areas is attributed to the prevalence of discrimination against women. The expenditure on education was observed to be more for boys in all the three cultural zones of Punjab

Girls understand clearly that after passing high school, they will not be given chance to attain higher education as those facilities are available in cities. However they are of the view that education alone may not be sufficient to enhance status unless it engages employment as well (Hogan et al. 1999). Parents fear that they will not be able to provide any security to their daughter at far away places. In contrast parents allow their sons to travel on their own to attend school/college. Among low socio economic status parents discourage girls for getting higher education as their services are required for house hold work. Giving education to girls is not much culturally accepted. At the same time parents fear if their daughters achieve higher education they may not be able to find suitable marriage partners for their daughters. Respondents also gave different family reasons for imparting education to their daughters and sons. Parents were interested to impart education to their daughters so that they become literate, able to read and write letters, atleast manage their household property, be aware about different happenings and developments in the society, increasing marriage prospects and also perceive that educated girls would be able to help their children in their studies and manage families well. Very few parents wanted girls to get jobs as well. But education is important for sons thinking that boys should be economically independent and get good jobs in the formal organizations, which would in turn enhance the status of the family. Interestingly, a girl getting higher education is not socially appreciated instead of appreciating the personal talent of the girl; parents get the social advice to educate the girl to a certain minimum level.

The scholars (Desai and Krishna 1987; Gupta 1995; Singh 1995) have maintained that status of women cannot be elevated till there is disparity between the two sexes at the educational level.

\section{Household Responsibilities}

The girls in all the cultural zones were involved in different household chores such as cooking, knitting, sewing, embroidery and these activities were given upper hand It was a common practice in each zone that with the learning and practicising of these activities a girl needs to 
prepare items for dowry, which are to be given at the time of her marriage. Hence, it becomes really difficult to draw a line with regard to time spent on such activities. It is appreciable to mention that in spite of such demanding work and expectations girls were academically performing well in comparison to their brothers. Another activity, which was covered under household work, pertains to the care of livestock. The girls are not given any formal training for fodder, milking but they learn to manage the milk produce and take care of cow dung. The activities pertaining to animals were treated as women's activities and covered under the broad category of household work. As reported by girls they had to do majority of the other household tasks such as sweeping, mopping, cooking, milking the animals and washing clothes and taking care of younger siblings and grand parents. Depending on their schoolwork and examinations and other assignments girls distribute the time between household chores and schoolwork. The girls do sweeping and mopping in morning hours, which take about at least half hour. Cleaning utensils takes 15-20 minutes and cooking takes one hour. The girls mostly prepare the food in the evening hours. All these household chores become very important in spite the amount of schoolwork and examinations. They manage to distribute the work with respect to demands of their school work. Girls from low socio economic status also assisted their families in doing fieldwork. During sowing and harvesting seasons they even missed their school. In comparison brothers were not assigned any type of household work, as the boys have different role performances for matter related to chores outside home, field work or feeding animals etc. As reported by Seth 1990 and Singh 1995 in certain situations the female child is forced to drop out because of domestic work, economic conditions, importance given to male child, early marriage, distance of schools and a fear of alienation of girls .

\section{Upbringing Practices}

Regarding the upbringing practices of rural girls, the condition of girls seemed to be more or less same among all culture zones of Punjab. Regarding food distribution to children of both genders except the girls from villages of Bathinda district none of the girls in the cultural zones reported any discrimination. The different studies (Mcnay 1995; Singh and Mehta 1988) have also supported that in rural areas sex biases prevailed with regard to allocation of food, breast feeding and immunization etc. All males in the family were given food first, whereas girls were told to wait and eat at the end with their mothers whether food remains for them or not. If due to any reason, no food is left for them the girls will have to take the chappattis with pickle, chutney, tea, buttermilk or curd. Likings and dislikings of various foods for male children are well looked after than their sisters. The preferred foods for male children are given are non-vegetarian food, milk and milk products and eggs. Boys are given rich foods as the family thinks that males need more of energy to do all sorts of physical work in comparison to their sisters. On the other hand girls are devoid of such food items as their mothers think that with the consumption of rich protein diet girls mature earlier or may gain weight.

In addition to food, boys have the freedom to study as much as they want to therefore the expenditure on education and clothes was more for boys in all three cultural zones of Punjab.The boys spend more money on recreational activities also as girls are barred from going out of the house, market and atending public functions etc. But the expenditure on marriage of girls is more for girls than marriage of boys in all the cultural zones of Punjab due to dowry, gifts to in laws, and for other hospitality arrangements at marriage.

\section{Economic Aspects}

Most of the girls (80\%) in all the three cultural zones were aware of the vocational facilities like computer training, stitching, embroidery, nursing, beautician etc but they were not able to approach these training centres as either they are at distant from their village or due to economic constraints to bear the expences. They were also not aware of the detailed facilities /programmes provided by different institutions for entrepreneurial purposes, procedure to be followed in these institutions and bank/post transactions. But one thing is clear that with the introduction of new technology and changed mode of production they want to gain knowledge and practice the management of entrepreneurial activities indicating an improvement in their status. All the girls $(100 \%)$ are interested in taking up skill oriented training and want to pursue it as a career. However due to patriarchal social structure 
women are still discriminated with regard to low accessibility to credit and loans in their own right, right to market the produce and ownership of land (Jain 1985, United Nations 1987). United Nations reports mention that women form onethird of the total labour force of the world do most of the unpaid work. They receive only 10 percent of the world's income and own less than one percent of the world's property (UNESCO 1980; World Bank 1992) .One of the reason as reported by Hoffman (1988), in India sons are seen as source of economic security. Parents believe sons will support them in their old age, while daughters belong to the husband's family and take on the responsibilities of the husbands' family. Desai (1994) points out that the perception that sons are the major source of economic security in old age is so strong in the north that "many parents, while visiting their married daughters, do not accept food or other hospitality from them. However, given women's low independent incomes and lack of control over their earnings, few can provide economic support to their parents even if parents were willing to accept it."

\section{Social Aspects}

The position of girls could be viewed by taking into account number of prevailing customs and social practices. Among all cultural zones of Punjab, none of the girl was allowed to be member of any youth club/co-operative body. The girls were never motivated to establish a club or to be a member of club nor do their mothers take the initiative to encourage their daughters to be socially active because of the existing social taboos. The girls were never given permission to attend any social function alone within the village or outside village. A girl was not allowed to move alone in the village to visit anybody. For going out some family member had to escort her. She was not allowed to stand in front of the main gate of the house as it points out to her moral character.

Parents were also not in favor of granting them freedom to interact with the members of opposite sex. With regard to intra-family power dynamic, it was seen that no doubt authority is vested with their father or brother but girls were rarely involved in family decision process. The matters related to sale and purchase of property was managed mostly by elder males, in that case sometimes their mothers also may not have much say. The patriarchal system does not allow women to be the head of a household. The social definitions force them to play only expressive roles and assume the status of dependant person. It is perhaps for this reason that land ownership still remains with the male members of the family and even in the day to day family decision making process they play only a subordinate role indicating their low status (Madan 1979; Census of India 1981). Parents grant freedom to the male children to play outside, visit anybody in the village or even may go to nearby city without anybody to escort them. This was rather considered a part of rearing practice that boys should learn to defend for themselves. In contrast, there was tendency on the part of parents to encourage their daughters to remain inside the house or nearby because of security purposes. By this attitude the parents develop a psychological dependency in their female children and this dependency is being practiced in such a way that even after their marriage the dependency is being remains with them. Though some kind of discrimination was seen among rural girls interestingly the voting behavior pattern also indicates the authority of men folk. It is only the elder male member who suggests the voting pattern. Overall, a girl becoming socially active means bringing bad name to family. "There seems to be a consensus that higher female mortality between ages one and five and high maternal mortality rates result in a deficit of females in the population.

\section{Health Aspects}

The girls from all villages reported that on being sick they get all the medical facilities just like their brothers. With respect to knowledge of balanced food and food related deficiencies very few girls (10\%) in Doaba area were aware about food related deficiencies. As reported by Coonrod (1998) females in India receive less health care than males. Many women die in childbirth of easily prevented complications. Working conditions and environmental pollution further impairs women's health Most of the girls $(85 \%)$ in Malwa, $80 \%$ in Majha and $90 \%$ in Doaba were ignorant about the food deficiencies such as anemia, calcium and protein etc. Girls belonging to low socio economic status from all the zones expressed that during the harvesting season long hours of fieldwork make them tired and weak. Excessive physical activity i.e. working for long 
hours in the fields cause bad effect on the health of girls. Research studies quote that deaths of young girls in India exceed those of young boys by over 300,000 each year, and every sixth infant death is specifically due to gender discrimination." Of the 15 million baby girls born in India each year, nearly 25 percent will not live to see their $15^{\text {th }}$ birthday. The girls had little knowledge about personal care, as they did'nt find it necessary to take out time for such things.

\section{Marriage}

In $100 \%$ of the cases parents arranged the marriages in rural areas. The same criteria applies for boys, the appropriate age for marriage for boys to get married is the age of 25-27 years when they are mature enough to carry the household and financial responsibilities. Regarding the choice in selection of marriage partner, the girls do not have any say in this decision. It is upto the parents /elders in the family to decide upon that what type of marriage partner best suits their daughter. The girls in all the zones were of the view that ideal age for marriage of a girl is $20-23$ years as by that time she completes her studies, physically mature and has the ability to take decision and may be economically independent. All the girls agreed that more the age gap between both the marriage partners the more were the adjustment problems. Ideal age gap between both the partners should be 2-3 years. Regarding the criteria for mate selection the girls from all cultural zones remarked that the boy should be educated and employed in urban area as their first preference, followed by good looks, family background and land holding.

\section{CONCLUSIONS}

Keeping in view the findings of the study, it can be concluded that sex discrimination still prevails almost in all cultural zones of Punjab in areas of social activities, feeding pattern, recreational activities, upbringing practices and education etc. For the removal of inequality, based on sex and discriminatory practices against the women, it is important that the status of women can be elevated only when they are made free from economic, social and psychological dependency.

\section{REFERENCES}

Coonrod C 1998. Chronic Hunger and the Status of Women in India. www.thp.org/sai00/India/subju gation.htm

Desai N 1957. Women in Modern India. Bombay: Vora Publishers.

Desai N, Krishan R 1987. Women and Society in India. Delhi: Ajanta Publishers.

Desai Sonalde 1994. Gender Inequalities and Demographic Behavior: India. New York: The Population Council, Inc.

Gupta V 1995. Status of girl child in rural schools of Himachal Pradesh- A case Study. Him Shiksha, 25(3).

Hogan DP, Berhanuand B, Hailermarium A 1999. Household organization, women's autonomy and contraceptive behavior in southern Ethopia. www.ncbi.nim.gov/pubned/10674326

Hoffman LW 1988. Cross -cultural differences in child rearing goals. In: RA LeVine, PM Miller, MM West (Eds.): Parental Behavior in Diverse Societies. San Francisco: Jossey-Bass, Pp. 99-120

Jain D 1985. Women's Economic Roles and Women's Employment- The linkages and Policy Implications. Paper presented at the International Seminar on Women and Development, Jaipur: ISST.

Madan TN 1979. The Hindu Women at House, in Indian Women Purdah to Modernity. New Delhi: Vikas Publishing House.

McNay Kirsty 1995. Fertility and Frailty: Demographic Change and Health and status of Indian women. Economic and Political Weekly, Vol. XXX, No.43, Oct. 28

Rana Sushma 1995. Women and Education: New challenges. Him Shiksha Vol.25, No.3, July September.

Ramalingaswami Vulimiri, Jonsson Urban, Rohde, Jon. 1996. The Asian Enigma. The Progress of Nations. New York: UNICEF.

Seth SC 1990. Women in 2000. Viewpoint Hamari. Gosthi No. 2 Vol. IV.

Shah V 1998. SAARC Decade of the girl child. Social Welfare, 44 (1-12): 8-9.

Singh K 1995. Preparing Women for Developing Society: Role of Non formal Education. Him Shiksha, Vol.25, No.3, July-September.

Singh R, Mehta N 1988. Social Determinants of Women's Health. Guru Nanak Journal of Sociology, 9(2): www.mcgill.ca/files/edas/women development pdf.

United Nations Educational Scientific and Cultural Organizations (UNESCO) 1980. Socio-Cultural Factors Affecting Productivity of Industrial WorkersA Report. New York: UNESCO

United Nations, 1987. Achievements of the United Nations Decade for Women in Asia and the Pacific. Bangkok: Economic and Social Commission for Asia and the Pacific.

Verma RK, Ghadially R 1985. Mothers sex role attitudes and demands for independence training in boys and girls. Indian Journal of Social Work, 46: 105-110. 